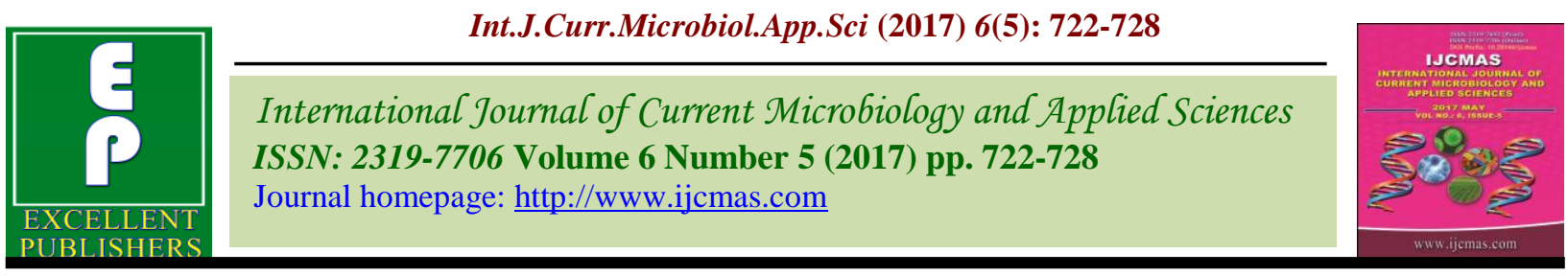

Original Research Article

https://doi.org/10.20546/ijcmas.2017.605.081

\title{
In vitro Mass Propagation of Endangered Terrestrial Orchid Phaius tankervilliae (L'Her.) Blume through Green Seed Pod Culture
}

\author{
Rocky Thokchom*, Soumen Maitra and Sachin Sharma
}

Department of Floriculture, Medicinal and Aromatic Plants, Faculty of Horticulture, Uttar Banga Krishi Viswavidyalaya, Pundibari, Cooch Behar - 736165, West Bengal, India

*Corresponding author

\begin{tabular}{|c|c|}
\hline & A B S T R A C T \\
\hline & Phaius tankervilliae (L'Her.) Blume is one of the most attractive and horticulturally \\
\hline Keywords & $\begin{array}{l}\text { valuable ground orchids of the world. Due to illegal collection for trade and consumption } \\
\text { and loss of habitat, the population of this species has decreased rapidly at an alarming rate }\end{array}$ \\
\hline $\begin{array}{l}\text { Phaius } \\
\text { tankervilliae, } \\
\text { in vitro, seed } \\
\text { germination, } \\
\text { Kinetin, NAA. }\end{array}$ & $\begin{array}{l}\text { in natural habitats. In vitro seed germination and seedling development of Phaius } \\
\text { tankervilliae technique was successfully established for rapid multiplication using } 0.8 \% \\
\text { (w/v) agar solidified MS medium supplemented with different concentrations and } \\
\text { combinations of Kinetin (Kin) and NAA. MS medium supplemented with } 1.0 \mathrm{mg} \mathrm{L}^{-1} \mathrm{Kin}+ \\
1.0 \mathrm{mg} \mathrm{L}{ }^{-1} \text { NAA was the most ideal condition for early seed germination (2.87 weeks), }\end{array}$ \\
\hline Article Info & $\begin{array}{l}\text { fastest protocorm formation }(5.07 \text { weeks), tallest shoots }(6.85 \mathrm{~cm}) \text { and maximum number } \\
\text { of roots per plant }(6.20) \text {. However, maximum number of shoots }(52.27) \text { per culture and }\end{array}$ \\
\hline $\begin{array}{l}\text { Accepted: } \\
04 \text { April } 2017\end{array}$ & $\begin{array}{l}\text { maximum number of shoots with roots }(50.27) \text { were produced when the plantlets were } \\
\text { transferred to MS basal medium supplemented with } 1.5 \mathrm{mg} \mathrm{L}^{-1} \mathrm{Kin}+1.0 \mathrm{mg} \mathrm{L}^{-1} \text { NAA. }\end{array}$ \\
\hline $\begin{array}{l}\text { Available Online: } \\
10 \text { May } 2017\end{array}$ & $\begin{array}{l}\text { The well developed in vitro rooted plantlets were hardened successfully in the potting } \\
\text { mixture containing only vermiculite }(86.00 \%) \text { followed by vermiculite + vermicompost }\end{array}$ \\
\hline & (20) \\
\hline
\end{tabular}

\section{Introduction}

Phaius tankervilliea, commonly known as Nun's Orchid or Lady Tankerville's Swamp Orchid belongs to the sub-family Epidendroideae. It is a large terrestrial orchid with striking flowers that blooms from April to July. It is distributed from India, Sri Lanka and Southern China, through Thailand and Malaysia to Indonesia, Australia and the Pacific islands (Cheng et al., 2012). P. tankervilliea has slender leaves, graceful greenery, and can be used as a potted plant, a garden plant, or as cut flowers or leaves (Mukherjee, 1979; Lee, 1989; Chang and Jian, 2010). Not only its ornamental values, the leaves and flowers are also used to extract natural dyes (Mahanta and Tiwari, 2005). Paste prepared from the pseudobulb of this species is used to cure swellings of hands and legs (Buragohain et al., 2015; De and Singh, 2016). Because of its high ornamental and medicinal properties, the plant is exploited illegally from the natural environment for trade and consumption. It has also been experiencing a steady decline due to destruction of natural forest areas. This orchid species has been categorized as endangered species, under the Environmental Protection and Biodiversity Conservation Act (Briggs 
and Leigh, 1996) and has become one of the objects of concern to the conservationists due to high sensitivity to environmental changes (Rasmussen, 1995). Hence, it is essential to take necessary measures to conserve and propagate these endangered orchid species. For mass propagation of several commercially important orchids, tissue culture technique has been widely adopted (Malabadi et al., 2005).

Orchid's seeds are very minute, numerous and non-endospermic. Germination rate is very slow (8-10 years) and need mycorrhizal association for germination in nature (Deb \& Pongener, 2011). Tissue culture has become the standard method of propagation for the conservation of orchids. This problem can be overcome by tissue culture technique (Pradhan et al., 2013). In vitro asymbiotic germination is possible only by tissue culture method because it substitutes the action of fungus with a nutrient medium (Pant et al., 2011). Rapid in vitro germination of seeds and development take place in the controlled environment and requires no competition with fungi and bacteria. Asymbiotic seed germination of orchids is greatly influenced by several factors such as developmental stage of embryos, age of green pod and different nutrient media with adjuvant and plant growth regulators (Arditti, 1979).

With this view, the present study was carried out to establish an in vitro protocol for mass propagation and conservation of Phaius tankervilliae using axenic seed.

\section{Materials and Methods}

\section{Plant materials}

Seeds of Phaius tankervilliae (L' Her.) Blume were collected from Hans Florist, Kalimpong, West Bengal, India. Immature pods of Phaius tankervilliae were used as explants for the present study.

\section{Sterilization}

The seed pods were washed with running tap water along with 3-4 drops of Tween 20 for about half an hour. Then pods were then treated with Carbendazim 50 W.P. @ $1 \mathrm{~g} \mathrm{~L}^{-1}$ of water for half an hour followed by streptomycin sulphate $(9 \%)+$ tetracycline hydrochloride (1\%) [Plantomycin] @ $1 \mathrm{~g} \mathrm{~L}^{-1}$ for half an hour. The pods were then rinsed repeatedly using sterilized double distilled water in the laminar air flow chamber. The pods were again surface sterilized sequentially with $70 \%$ ethyl alcohol for 1 minute, $0.1 \% \quad \mathrm{HgCl}_{2}$ (Mercuric Chloride) solution for 3 minutes and finally rinsed thoroughly 5-6 times with sterile distilled water. Sterilized capsules were cut horizontally by a sterile surgical blade. Around $200 \mathrm{mg}$ seeds were inoculated per culture vessel.

\section{Culture medium and incubation}

In the present investigation, full strength of Murashige and Skoog (MS) medium supplemented with or without plant growth regulators viz. Kin (0.5 to $2.0 \mathrm{mg} / \mathrm{l})$ either alone or in combination with NAA $\left(1.0 \mathrm{mg} \mathrm{L}{ }^{-}\right.$ ${ }^{1}$ ) were used for in vitro seed germination and seedling development. Basal medium were fortified with $30 \mathrm{~g} \mathrm{~L}^{-1}$ sucrose and with or without different plant growth regulators like kinetin and NAA. For gelling of the medium, agar $(0.8 \% \mathrm{w} / \mathrm{v})$ was used and was adjusted at $\mathrm{pH} 5.8$ by using $0.1 \mathrm{~N} \mathrm{NaOH}$ or $\mathrm{HCl}$. Agar was dissolved by boiling the mixture and about $100 \mathrm{ml}$ of media was dispensed into each culture jar. The jars containing the media were autoclaved at $121^{\circ} \mathrm{C}$ for $20 \mathrm{~min}$ at 1.05 $\mathrm{Kg} \mathrm{cm} \mathrm{cm}^{-2}$ pressure. All cultures were maintained at $25 \pm 2^{\circ} \mathrm{C}$ under $350-500$ lux illumination for $16 / 8 \mathrm{hrs}$. (light/dark) photoperiod using white fluorescent tube lights (Philips, India). 


\section{Inoculation of seeds}

The surface sterilized immature green pods were kept on the sterilized Petri dish containing sterilized blotting paper for absorbing the excess moisture from the pods. The pods were then cut longitudinally with the help of surface sterilized surgical blade and scooped out the immature seeds with the help of sterilized spatula. The seeds were then spread over the surface of the medium supplemented with or without, either in combination of kinetin and NAA or kinetin alone. Cultures were sub-cultured into fresh medium once in every eight weeks and were replicated thrice for each treatment. The initiation and rate of seed germination was recorded every week. To prevent microbial contamination, the entire experiment was performed under aseptic condition in the laminar air flow hood.

\section{Data analysis}

In the present experiment, ten culture jars were used in each treatment and each treatment were replicated thrice in case of seed germination, growth and development of the seedlings. For acclimatization of the seedlings, each treatment was replicated four times. The experiment was laid out using completely randomized block design and the percentile data of the experiments were assumed and subjected to square root transformations.

\section{Results and Discussions}

The seed germination rate of $P$. tankervilliae was found to be variable in hormone free MS medium and MS medium supplemented with various concentration of Kinetin and NAA (Table 1). Quickest germination of seeds was obtained on MS basal medium supplemented with $1.0 \mathrm{mg} \mathrm{L}^{-1} \mathrm{Kin}+1.0 \mathrm{mg} \mathrm{L}^{-1}$ NAA (2.87 weeks) which was also found to be the best for fastest protocorm formation (5.07 weeks). The hormone free MS basal medium, though favored seed germination, took the longest day (16.47 weeks) for germination and protocorm formation (23.93 weeks) when compared to those basal medium supplemented with hormones.

The results obtained from the experiment shows that optimum amount of Kinetin (1.0 to $1.5 \mathrm{mg} \mathrm{L}^{-1}$ ) when combined with $1 \mathrm{mg} \mathrm{L}^{-1}$ NAA was found to be more effectual for seed germination and subsequent development of this terrestrial orchid. MS medium supplemented with $2.0 \mathrm{mg} \mathrm{L}^{-1} \mathrm{Kin}$ alone and combinations of Kinetin $\left(0.5-1.5 \mathrm{mg} \mathrm{L}^{-1}\right)+$ NAA $\left(1.0 \mathrm{mg} \mathrm{L}^{-1}\right)$ have the highest capability of forming protocorm-like bodies from the immature seeds as compared to the rest of the treatments (Table 1).

In the present study, MS medium alone and MS medium fortified with different concentrations and combinations of hormones were found to be efficient for immature seed germination upto the development of protocorms. This might be due to the chemical composition of MS medium which is highly enriched with macro and micro elements with different vitamins that favored seed development. MS basal medium fortified with different plant growth hormones improve the nutritional status of the basal medium and favored earlier seed germination and protocorm formation. The result is in conformity with the findings of Arditti et al., (1981).

Protocorm undergoes further differentiation on MS medium alone and MS basal medium fortified with different concentrations and combinations of growth hormones. MS medium supplemented with $1.0 \mathrm{mg} \mathrm{L}^{-1} \mathrm{Kin}+$ $1.0 \mathrm{mg} \mathrm{L}^{-1}$ NAA favored the development of complete seedlings directly from seeds after 20 weeks of culture. 
Table.1 Effect of growth regulators in MS medium on seed germination and seedling development of Phaius tankervilliae (L’Her.) Blume

\begin{tabular}{|c|c|c|c|c|c|c|c|c|}
\hline Treatment & $\begin{array}{l}\text { Treatment } \\
\text { combinations }\end{array}$ & $\begin{array}{l}\text { Initiation of } \\
\text { germination } \\
\quad \text { (weeks) }\end{array}$ & $\begin{array}{l}\text { Development of } \\
\text { protocorm } \\
\text { (weeks) }\end{array}$ & $\begin{array}{c}\text { Capability of } \\
\text { immature seeds } \\
\text { forming } \\
\text { protocorm-like } \\
\text { bodies } \\
\end{array}$ & $\begin{array}{l}\text { Number of } \\
\text { shoots per } \\
\text { bottle }\end{array}$ & $\begin{array}{l}\text { Height of } \\
\text { shoot }(\mathrm{cm})\end{array}$ & $\begin{array}{l}\text { No. of shoots } \\
\text { with roots }\end{array}$ & $\begin{array}{l}\text { No. of roots } \\
\text { per plant }\end{array}$ \\
\hline $\mathrm{M}$ & $\mathrm{MS}+0$ & 16.47 & 23.93 & + & - & - & - & - \\
\hline $\mathrm{MK}_{1}$ & $\mathrm{MS}+0.5 \mathrm{mg} / \mathrm{l} \mathrm{Kin}$ & 8.73 & 11.07 & ++ & 35.33 & 3.03 & 26.07 & 3.07 \\
\hline $\mathrm{MK}_{2}$ & $\mathrm{MS}+1.0 \mathrm{mg} / \mathrm{l} \mathrm{Kin}$ & 7.00 & 9.40 & ++ & 38.13 & 4.99 & 29.20 & 4.47 \\
\hline $\mathrm{MK}_{3}$ & $\mathrm{MS}+1.5 \mathrm{mg} / \mathrm{l} \mathrm{Kin}$ & 6.40 & 8.73 & ++ & 32.47 & 4.75 & 22.73 & 4.40 \\
\hline $\mathrm{MK}_{4}$ & $\mathrm{MS}+2.0 \mathrm{mg} / \mathrm{l} \mathrm{Kin}$ & 4.73 & 7.20 & +++ & 27.87 & 4.18 & 18.80 & 3.13 \\
\hline $\mathrm{MK}_{1} \mathrm{~N}_{1}$ & $\begin{array}{l}\mathrm{MS}+0.5 \mathrm{mg} / \mathrm{l} \mathrm{Kin}+1.0 \\
\mathrm{mg} / \mathrm{l} \mathrm{NAA}\end{array}$ & 5.93 & 8.07 & +++ & 43.13 & 6.00 & 36.80 & 5.13 \\
\hline $\mathrm{MK}_{1} \mathrm{~N}_{2}$ & $\begin{array}{l}\mathrm{MS}+1.0 \mathrm{mg} / \mathrm{l} \mathrm{Kin}+1.0 \\
\mathrm{mg} / \mathrm{l} \text { NAA }\end{array}$ & 2.87 & 5.07 & +++ & 49.27 & 6.85 & 44.93 & 6.20 \\
\hline $\mathrm{MK}_{1} \mathrm{~N}_{3}$ & $\begin{array}{l}\mathrm{MS}+1.5 \mathrm{mg} / \mathrm{l} \mathrm{Kin}+1.0 \\
\mathrm{mg} / \mathrm{l} \mathrm{NAA}\end{array}$ & 4.07 & 6.20 & +++ & 52.27 & 5.67 & 50.27 & 5.67 \\
\hline $\mathrm{MK}_{1} \mathrm{~N}_{4}$ & $\begin{array}{l}\mathrm{MS}+2.0 \mathrm{mg} / \mathrm{l} \mathrm{Kin}+1.0 \\
\mathrm{mg} / \mathrm{l} \mathrm{NAA}\end{array}$ & 5.33 & 7.47 & ++ & 46.87 & 3.75 & 41.67 & 5.20 \\
\hline \multicolumn{2}{|l|}{ SEm \pm} & 0.33 & 0.38 & & 1.28 & 0.16 & 1.25 & 0.23 \\
\hline \multicolumn{2}{|l|}{ CD at $5 \%$} & 0.98 & 1.13 & & 3.82 & 0.48 & 3.72 & 0.69 \\
\hline
\end{tabular}

Table.2 Effect of different hardening media on percent survivability of seedlings of Phaius tankervilliae (L'Her.) Blume

\begin{tabular}{|l|c|c|}
\hline Hardening media & Medium ratio & Survival (\%) \\
\hline Garden soil + sand + vermicompost & $1: 1: 1$ & $31.00(33.75)$ \\
\hline Garden soil + sand & $1: 1$ & $53.00(46.73)$ \\
\hline Vermiculite & 1 & $86.00(68.18)$ \\
\hline Vermiculite + vermicompost & $1: 1$ & $71.00(57.52)$ \\
\hline Vermiculite + sand & $1: 1$ & $59.50(50.51)$ \\
\hline \multicolumn{2}{|c|}{ SEm \pm} & $\mathbf{1 . 8 5}$ \\
\hline CD at 5\% & $\mathbf{5 . 5 8}$ \\
\hline
\end{tabular}




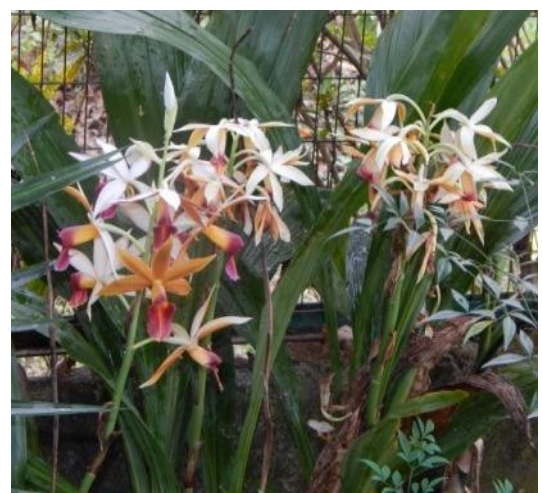

Fig.1. Phaius tankervilliae in full bloom

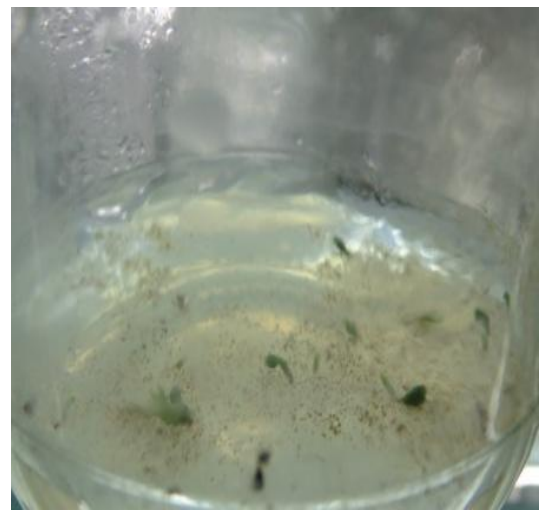

Fig.4. Seed germination and PLBs formation after 7 weeks of culture in MS $+1.0 \mathrm{mg} / \mathrm{l} \mathrm{Kin}+1.0 \mathrm{mg} / \mathrm{l} \mathrm{NAA}$

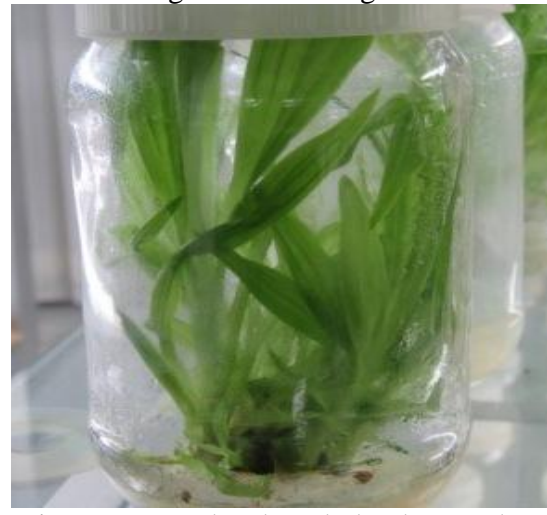

Fig.7. In vitro developed plantlets ready for acclimatization

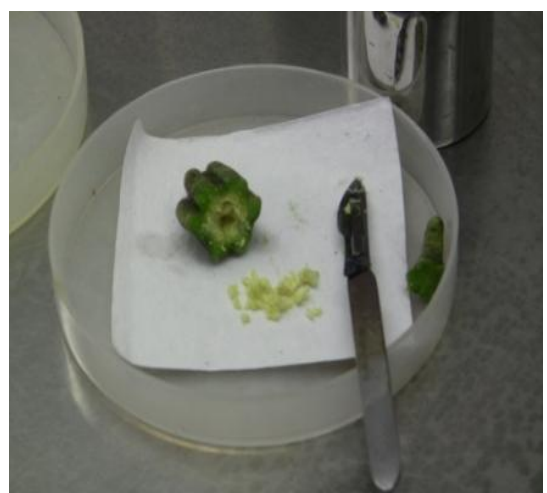

Fig.2. Seeds extraction from the green pod of Phaius tankervilliae

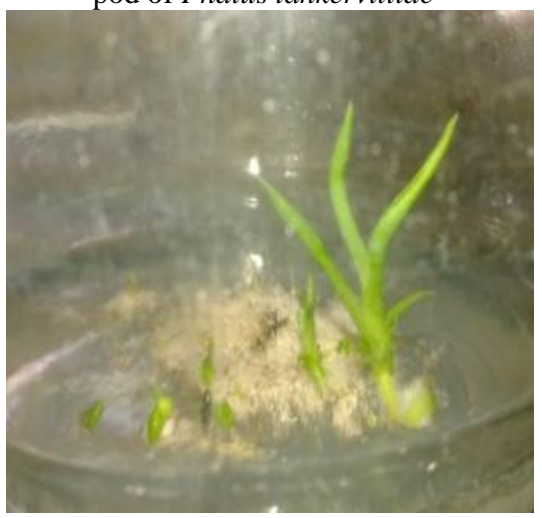

Fig.5. Initiation of shoots after 12 weeks of culture

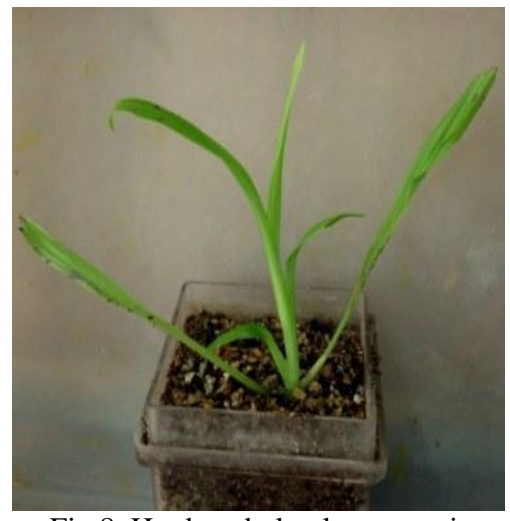

Fig.8. Hardened plantlet on potting mixture

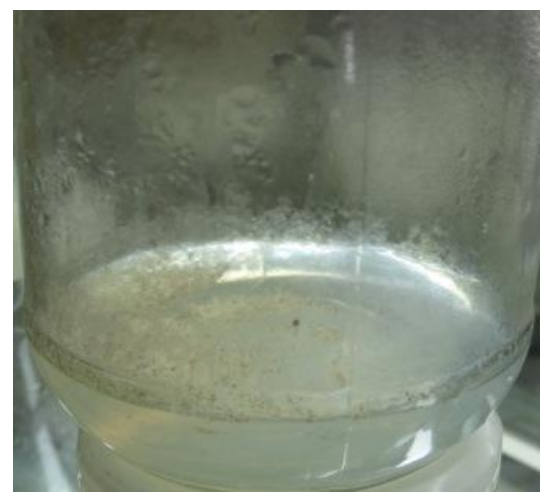

Fig.3. Hormone free MS media after 10 weeks of culture

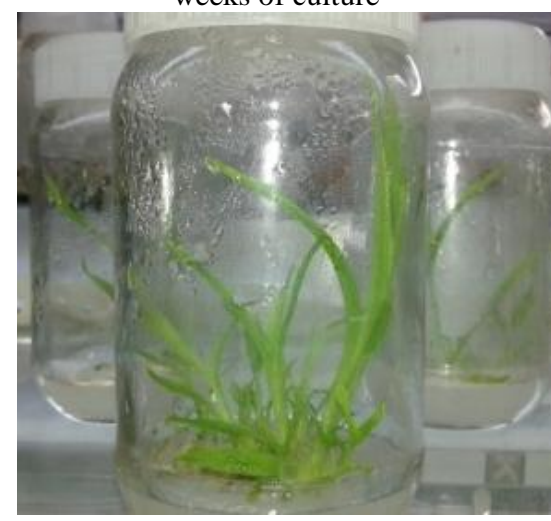

Fig.6. Shoot multiplication after 20 weeks of culture in MS $+1.5 \mathrm{mg} / \mathrm{l} \mathrm{Kin} \mathrm{+}$ $1.0 \mathrm{mg} / 1 \mathrm{NAA}$
The same hormonal composition was found effective for production of tallest shoot height $(6.85 \mathrm{~cm})$ as well as maximum number of roots per plant (6.20). However, MS medium when supplemented with $1.5 \mathrm{mg} \mathrm{L}^{-1} \mathrm{Kin}+1.0$ $\mathrm{mg} \mathrm{L}^{-1}$ NAA produced maximum number of shoots per culture (52.27) and maximum number of shoots with roots (50.27) per culture.
Seeds could not undergo further differentiation in hormone free MS medium because terrestrial orchids require more regulated conditions of hormones for immature seeds to develop into seedlings (Pant et al., 2011). The results from the above findings showed that hormone supplemented MS basal medium were found more effective for further growth and development of the 
seedlings. The well rooted in vitro regenerated Phaius seedlings were later removed from the culture media, washed repeatedly under running tap water to remove the adhered traces of semisolid agar medium and then treated the seedlings with fungicide (Carbendazim 50 W.P.) @ $1 \mathrm{~g} \mathrm{~L}^{-1}$ for 30 minutes followed by bactericide (Plantomycin) @ 1 $\mathrm{g} \mathrm{L}^{-1}$ for 30 minutes. Later, the seedlings were transferred in the plastic containers having different well sterilized growing medium consisting of garden sand, soil, vermiculite and vermicompost either alone or in combination at equal ratio. Among the different hardening media studied, vermiculite alone was found as suitable medium for hardening of Phaius seedlings in respect of survivability $(86.00 \%)$ (Table 2 ). The seedlings were kept inside the growth chamber maintaining a controlled temperature of about $25^{\circ} \mathrm{C}$ with a comparatively higher percentage of relative humidity $(80 \%)$ and light density of 4000 lux.

In conclusion, the present investigation reports an efficient and easy protocol for in vitro seedling development of Phaius tankervilliae using immature seeds as explant. Optimal use of Kinetin and NAA (1.0-1.5 mg $\mathrm{L}^{-1}+1.0 \mathrm{mg} \mathrm{L}^{-1}$ ) along with the MS basal medium was found to be the better hormonal combination in terms of seed germination, protocorm formation, growth and development of the seedlings. The well rooted in vitro plantlets can be successfully hardened ex vitro using well sterilized vermiculite alone. This protocol might be useful for mass propagation and ex-situ conservation of this rare and valuable orchid species.

\section{References}

Arditti, J. 1979. Aspects of the physiology of orchids. Adv. Bot. Res., 7: 422-638.

Arditti, J., Michaud, D.J. and Oliva, A.P. 1981. Seed germination of North American Orchids. I. native California and related species of Calypso, Epipactis, Goodyera, Piperia, and Platanthera, Botany Gazette, 142(4): 442-453.

Briggs, J.D. \& Leigh, J.H. 1996. Rare and threatened Australian plants, CSIRO, Publishing, Collingwood.

Buragohain, B., Chaturvedi, S.K. and Puro, N. 2016. Pollination Biology of Phaius tankervilleae (Banks ex L' Herit) Bl. (Orchidaceae). Int. J. Plant Reproductive Biol., 8(1): 75-81

Chang, C. and Jian, W.T. 2010. The growth evaluation of Phaius tankervilleae cultivation in botanical garden. Seed Nursery, 12: 13-22.

Cheng, S.F., Yeh, C.H., Jan, C.H.and Chang, D.C.N. 2012. Growth and development of Phaius tankervilliae (Banks) Blume when inoculated with orchid mycorrhizal fungi. African J. Agri. Res., 7(42): 5644-5652.

De, L.C. and Singh, D.R. 2016. Post-harvest management and value addition in orchids. Int. J. Biol. Sci., 3(1): 14-35.

Deb, C.R. and Pongener, A. 2012. Studies on the in vitro regenerative competence of aerial roots of two horticultural important Cymbidium species. J. Plant Biochem. Biotechnol., 21: 1-7.

Lee, M.C. 1989. A study of growth habits and propagation of Phaius tankervilleae. Master thesis, Department of Horticulture, National Taiwan University, p. 95.

Mahanta, D. and Tiwari, S.C. 2005. Natural dye-yielding plants and indigenous knowledge on dye preparation in Arunachal Pradesh, Northeast India. Curr. Sci., 88(9): 1474-1480.

Malabadi, R.B., Mulgund, S.G. and Kallappa, N. 2005. Micropropagation of Dendrobium nobile from shoot tip sections. J. Plant Physiol., 162: 473478.

Mukherjee, A. 1979. Ornamental Phaius as 
house plant. Indian Hort., 24: 23-28.

Pant, B., Shrestha, S. and Pradhan, S. 2011. In vitro seed germination and seedling development of Phaius tankervilleae (L'Her.) Blume. Scientific World, 9(9): 50-52.

Pradhan, S., Regmi, T. Parmar, G. and Pant, B. 2013. Effect of different media on in vitro seed germination and seedling development of Cymbidium aloifolium
(L.) Sw. Nepal J. Sci. Technol., 14(1): 51-56.

Rasmussen, H., Andersen, T.F. and Johansen, B. 1990. Temperature sensitivity of in vitro germination and seedling development of Dactylorhiza majalis (Orchidaceae) with and without its mycorrhizal fungus. Plant Cell Environ., 13: 171-177.

\section{How to cite this article:}

Rocky Thokchom, Soumen Maitra and Sachin Sharma. 2017. In vitro Mass Propagation of Endangered Terrestrial Orchid - Phaius tankervilliae (L'Her.) Blume through Green Seed Pod Culture. Int.J.Curr.Microbiol.App.Sci. 6(5): 722-728. doi: https://doi.org/10.20546/ijcmas.2017.605.081 